Gender, Work and Organization. Vol. 12 No. 3 May 2005

\title{
Gender and National Identity Constructions in the Cross-Border Merger Context
}

\author{
Janne Tienari,* Anne-Marie Søderberg, Charlotte Holgersson and Eero Vaara
}

In this article we explore ways in which vertical gender inequality is accomplished in discourse in the context of a recent chain of cross-border mergers and acquisitions that resulted in the formation of a multinational Nordic company. We analyse social interactions of 'doing' gender in interviews with male senior executives from Denmark, Finland and Sweden. We argue that their explanations for the absence of women in the top echelons of the company serve to distance vertical gender inequality. The main contribution of the article is an analysis of how national identities are discursively (re)constructed in such distancing. New insights are offered to studying gender in multinationals with a cross-cultural team of researchers. Our study sheds light on how gender intersects with nationality in shaping the multinational organization and the identities of male executives in globalizing business.

Keywords : gender, discourse analysis, merger, cross-national, national identity

\section{Introduction}

Danish female senior academic: What role does the gender issue play in your department, in relation to recruitment ... and performance appraisal?

Danish male senior executive: To be honest, it doesn't matter at all. And that is a problem, because we have to make it play a certain role. And when it comes to this issue we have a different culture in Denmark from that in Sweden and Finland. They have made it a criterion of managerial success to get a better balance. In these countries, gender really is significant. To be quite honest, I feel that this is a rather odd way to look upon these things.

It is not entirely clear what 'we' refers to in the senior executive's statement above. If it refers to men, it is evident that it does not refer to just any men. 'We' constructs a particular Danish presence. 'They', in turn, refers to Swedes and Finns, 
presumably both men and women, who are said to deviate from what is constructed as Danish culture.

The exchange of words above is from an interview carried out in a research project on the making of a multinational company, which is built on a series of crossborder mergers and acquisitions in the Nordic region. In our view, statements such as 'when it comes to this [gender] issue we have a different culture in Denmark' beg interpretations and understandings that take into account the local, organizational and societal context of their production (Alvesson, 2003). Such analysis would shed new light on the ways in which national identities are discursively constructed and reconstructed in relation to gender in general and gender equality and inequality in particular. This question is seldom explicitly addressed in feminist studies on work, organization and management.

This article concerns the ways in which Danish, Finnish and Swedish male senior executives talk about the practically complete absence of women in the top echelons of a multinational company. This exclusion can be considered a visible symbol of gender inequality in the organization. We analyse ways in which male executives justify the present situation in interviews with researchers. Our analysis is based on conceiving the organization of gender (in)equality as something that is 'said' and 'done' (Acker, 1990; Gherardi, 1994; Smith, 1988).

We view language as a carrier of the social practices of doing gender, through which specific world-views, social relations and identities are created. We focus on how gender-related power relations are reproduced in and through the executives' social interaction with interviewers and study the role played by discursive constructions of gender and national identities in the maintenance of specific patterns of dominance. We reflect on how the discourses on gender (in)equality, on the one hand, and national differences, on the other, contribute to the construction of a specific world-view and specific social relations between the sexes and nationalities as well as intersections between these social categories ${ }^{1}$.

The Nordic countries are an interesting setting for discursive studies on the gendered nature of merging across borders. Denmark, Finland, Norway and Sweden are united by what has been termed the Nordic welfare model, and cultivate a gender-egalitarian image 
in societal discourses (Bergqvist, 1999; Borchorst et al., 2002). In contrast to societies marked by more conservative male dominance, women have made significant advances in the labour markets and organizations in Nordic welfare societies (Aaltio Marjosola, 2001; Duncan, 1998; Tienari et al ., 2002a). It may be, however, that the Nordic model is eroding. 'Global' influences, through manoeuvres such as cross-border mergers that are carried out under the supervision of foreign investors, arguably contribute to this shift. Multinational organizations operating in the Nordic region - such as the one focused on in this article - may become the pretext for particular procedures, norms and values that have significant gendered consequences (Hearn and Kovalainen, 2000; Meriläinen et al ., 2004).

In the following, we first discuss the theoretical underpinnings of our study. This is done in two parts: constructing gender and national identity and contextualizing identity constructions. We then go on to introduce our research setting and reflect on our engagement in the production and reading of empirical material, which comprises interviews with some 40 senior male executives in a multinational company. In the empirical part, we analyse managerial discourses on gender (in)equality and national differences and discuss these in relation to feminist research.

\section{Constructing gender and national identity}

Interview accounts by male senior executives - such as the one quoted above - reflect and (re)produce a particular gendered subtext (Benschop and Doorewaard, 1998). This subtext, or gendered order, expresses the ways in which women become marginalized and excluded through specific social, often discursive practices (Calás and Smircich, 1999). Through the analysis of interview statements we aim to capture the transitory attempts of male senior executives to give and make sense of organizational actions and events (Gioia and Chittipeddi, 1991; Søderberg, 2003). This includes retrospective interpretations of the nature of organizational processes and practices.

We have chosen vertical gender inequality - that is, the absence of women in top management - as a lens to enter the executives' discursive (re)constructions of the organizational order. In the interviews, they are unexpectedly exposed to questions on 
gender (as above: 'What role does the gender issue play ...'). They then attempt to justify the present state of affairs, which refers here specifically to the disproportion between men and women in top management. Such inequality is a potentially sensitive topic, at least in the Nordic context.

Accounting for inequality constitutes an inherent dilemma: the executives are likely to reproduce 'conflicting conceptions of the existence and justification of (in)equalities' (Benschop et al ., 2001, p. 14). In their justification talk, we suggest, male senior executives construct and reconstruct particular gendered identities. Although this has been extensively elaborated in earlier literature (Acker, 1990; Calás and Smircich, 1992; Czarniawska-Joerges, 1994; Hearn and Parkin, 1983), there are few in-depth studies focusing on elite men (Connell, 2000; Donaldson, 1993; Hearn, 1996), especially on how they perceive themselves vis-à-vis women in management (Holgersson, 2001; Wahl, 1995).

In analysing how powerful men discursively construct their position and identity, we are not 'muting' women. Concentrating on powerful men is consciously chosen to understand the production and reproduction of gender inequality. As gendered organizations, companies in the Nordic region have previously been analysed on the basis of female employees' and middle managers' voices (Acker, 1994; Jacobson and AaltioMarjosola, 2001; Meriläinen, 2000; Sundin, 2000; Tienari, 2000; Tienari et al., 2002a).

It is also evident that the social identities individuals (re)construct are manifold and intertwined. The cross-border merger context gives rise to many forms of identity construction. Sharpened cultural identification is an inherent part of intra- and interorganizational sense-making in mergers in general (Buono et al ., 1985; Nahavandi and Malekzadeh, 1988). In mergers and acquisitions across borders, national identification, as well as differentiating one's own from other national cultures, plays a crucial role (Calori et al., 1994; Gertsen et al., 1998; Lubatkin et al., 1998; Olie, 1994; Risberg et al., 2003; Søderberg and Vaara, 2003). Commitment to a national community or collective tends to intensify in the multinational setting (Vaara et al., 2003a). We argue that this intertwines with the construction of particular gender identities.

Male senior executives are not just men who manage; they are also likely to perceive themselves as belonging to a specific nationality. 2 As the executive quoted 
above puts it, 'we have a different culture in Denmark.' Michael Billig's (1995) concept of banal nationalism is useful for understanding national identities. It refers to how the construct of a nation is often reproduced and accepted in everyday life and rendered possible by mundane habits of language, thought and symbolism. When individuals use the term 'we' to refer to a specific national collective, for example, they are involved in the myriad of processes constructing and reconstructing the 'nation' (Anderson, 1983; Billig, 1995; de Cillia et al., 1999; Wodak et al., 1999).

There seems to be little feminist research in the field of organization and management studies dealing directly with issues of gender, nation and national identities. Related issues have, however, been raised in research on gender, race and ethnicity (Nkomo, 1992)3 and, in conjunction with these, class (Adib and Guerrier, 2003). This literature highlights patriarchal and racist structures and ideologies, problematizes the construction of femininity and masculinity in relation to old and new forms of domination and inequality and considers the problematics of identity construction in this space.

Complexities of race and ethnicity have been discussed by building on the feminist tradition of problematizing dichotomies of centre/margin and us/ them, thereby providing tools for analysing, for example, racism in contemporary societies (Collins, 1990; hooks, 1984). Specifically, Yuval-Davis (1997)

provides a critique of the gender-blindness of writings on gender and nationhood. She argues that constructions of nationhood involve specific constructions of masculinity and femininity and that gender relations are crucial to the reproduction of nations, culture and citizenship.

It is also possible to focus specifically on the transnational or multinational4 organization as a significant contemporary arena for constructing social identities such as gender and nationality. This path seems to hold promise with the research task at hand, although literature on the gendered nature and dynamics of the multinational organization is still relatively scarce. The deconstruction of the category of men provides a useful point of departure here. Collinson and Hearn (1994) and Connell (1995), for example, have provided frameworks for the analysis of men, masculinities and social divisions. It is probable that specific types of competitive men thrive in globalizing business (Kerfoot 
and Knights, 1993). In this vein, Hearn (1997) calls for more studies focusing on men, management and the (re)production of global domination. Multinational corporations and political constellations are significant contexts for this (re)production (Hearn and Kovalainen, 2000; Woodward, 1996). The crucial point is to analyse how men in powerful positions negotiate their position in the organization and within the broader society.

Connell (2001) argues that a specific type of masculinity has become prominent along with the reform of national and international economies and the rise of multinational organizations. According to Connell (2001), this transnational business masculinity is flexible, calculating and egocentric. It is marked by conditional loyalties (even to the company) and a declining sense of responsibility for others. In (re)constructing such an identity, individuals are likely to draw on discourses made possible by the cross-border aspects of organization. The perceived need for constant travelling, for example, may significantly inform the construction of transnational business masculinities. Calás and Smircich (1993) postulate that, in the apparently globalizing world, 'the household is extended up to the national border'. Traditional fixed perceptions of family obligations may become an increasing burden for women in the cross-border management of a multinational company. This becomes one of the many ways in which gender is implicated in the globalization of economic activities and organizations (Acker, 1998).

An increasingly popular way to build multinational organizations is to merge or acquire across national borders. As indicated above, mergers and acquisitions have attracted an overwhelming amount of research attention from the perspective of human resources, culture and integration. Nationalistic discourse prevails in cross-border mergers and national stereotypes are enacted to make sense of social interaction (Vaara et $a l ., 2003 \mathrm{~b})$. In other words, in the cross-border merger context, national sentiments may be mobilized as one among many discursive resources. Accounts of equality and inequality between the sexes may then be filtered or turned into discourse through perceived national similarities and differences. National identities thus (re)constructed may be strongly gendered (Hogan, 1999), while gendered identities may also invoke national identity. 
It is surprising that the gendered nature of mergers has seldom been acknowledeged and critically researched. Tienari (2000) and Tienari et al. (2002a, 2002b) argue that a merger is likely to result in a reconstitution of gender segregation. When the relative number of top positions decreases, the competition for the remaining positions also intensifies among the otherwise privileged (that is, a particular type of man). In Abrahamson's (2000) words, the dominant gender order is restored in the organization, even when it becomes subject to change efforts such as mergers. There is, in this sense, stability in change.

In sum, in exploring gender (in)equality in a merging multinational organization, the literature suggests that both the (re)construction of a 'global' masculine executive or transnational business masculinity - and the (re)construction of national identities need to be considered. It is, however, important to bear in mind that gender is always done and gender-related power relations are reproduced in a particular local, organizational and societal setting. To contextualize the (re)construction of gender and national identities in this article, we will briefly introduce the Nordic region.

\section{Contextualizing identity constructions: the Nordic region}

Viewing from the outside, geographical proximity and the web of common histories mean that the Nordic countries appear to be characterized by similar traits. Many of the institutions and traditions do have the same origins. The legislation in the four countries is relatively harmonized. The Nordic countries have, especially after World War II, worked consciously to create institutions and procedures to foster Nordic co-operation and values. Since 1954, for example, Nordic citizens have been able to move freely across the borders without a passport. In the same year the Nordic countries formed a common labour market.

Nordic states also form a community when it comes to the form of government and the social conditions offered to citizens. In cross-national comparisons of political systems, Denmark, Finland, Norway and Sweden are often grouped under the label of the 'Nordic welfare society' or the 'Nordic model' (Duncan, 1998; Esping-Andersen, 1990). All Nordic societies are deeply rooted democracies and highly developed welfare states. 
The 'Nordic model' refers to a particular version of a state with a large public sector, where all welfare services are financed by taxes and offered to everybody, regardless of their social status.

On a general level, the 'Nordic model' gives rise to shared attitudes towards issues of equality between the sexes. Nordic societies are characterized by a high degree of egalitarianism. A relatively weak malebreadwinner model prevails and the state provides extensively for social services such as public childcare, which enables active labour force participation for both sexes (Åström, 1995; Melkas and Anker, 1998; Meriläinen, 2000). There are societal and institutional normative pressures towards equality (Tienari et al., 2003). Public discourse in the Nordic context nurtures equality and equal opportunities (Bergqvist et al., 1999; Borchorst et al., 2002), especially in times of strong economic growth (Anttonen, 1997).

Specific outcomes are also clear. A high proportion of women are working full time. Balancing work and family life has increasingly become a question of individual solutions for men and women aspiring to succeed in the public sphere of life (Jacobson and Aaltio-Marjosola, 2001). This is in contrast to male-breadwinner societies such as the UK or Germany, where women are in practice typically forced to choose between a work career and having children (Meriläinen et al., 2004; Theobald, 1999; Tienari et al., 2002a).

The egalitarian 'Nordic ideal' has, however, also been questioned, as it has evidently given rise to a gender-segregated labour market, both horizontally and vertically. A high percentage of women in the Nordic countries work in femaledominated caring and household-related occupations, where wages are typically relatively low (Melkas and Anker, 1998). In addition, the upper echelons in organizations continue to be a male-dominated terrain, especially in the private sector (Højgaard, 2002; Statistics Sweden, 2002; SOU, 2003; Vanhala, 1999). Even in service industries where women dominate numerically — such as retailing and financial services - the top ranks consist almost exclusively of men (Sundin, 2000; Tienari, 2000).

In addition, despite their apparent similarities, it can be maintained that the Nordic countries do not form a monolithic block from a cultural point of view. In contrast to popular conceptions outside the Nordic context, the literature points to persisting 
perceptions of cultural difference between Danes, Finns, Norwegians, and Swedes (such as Laine-Sveiby, 1987, 1991; Vaara et al., 2003b). At the same time, the complex web of historical relations continues to flavour social interaction between representatives of the nations. For example, Finland was a colony of the Kingdom of Sweden between 1323 and 1809. For Finns, this colonial history makes Sweden a natural reference point. At times, the Finnish-Swedish relationship can mirror a little brother- big brother setting (Risberg et al., 2003; Vaara et al., 2003a). The relations between Swedes and Danes are more complex: on a symbolic level, there is no clear dominant party in the relationship (Gundelach, 2000).

In all, we contend that the construction and reconstruction of social identities is difficult to understand without a careful consideration of its sociocultural context. We now turn to our research setting and reflect on our engagement in the production and reading of interview material, where positions and meanings are negotiated between male senior executives and interviewers.

\section{'It didn't fit in': conducting and reading interviews}

This article originates from a research project that gathered scholars from four Nordic countries to study the making of the Nordea Group, a multinational Nordic company in the financial services industry. 5 Nordea was built through a series of domestic and crossborder mergers and acquisitions. The Swedish Nordbanken and the Finnish Merita Bank were each created by domestic mergers after the financial crises of the early 1990s. Next, the merger between Nordbanken and Merita in October 1997 led to the making of MeritaNordbanken. In September 1999, Merita-Nordbanken released its offer to buy the Norwegian Christiania Bank og Kreditkasse, where the State of Norway was a major shareholder. Merita-Nordbanken renewed its offer ten times until the Norwegian authorities finally granted permission to it to acquire Christiania Bank og Kreditkasse. This took place in October 2000. Meanwhile, in March 2000, Merita-Nordbanken merged with Unidanmark, which was, in turn, the result of a domestic Danish merger in 1999 between Unibank and Tryg-Baltica, an insurance company. The name Nordea signifying 'Nordic ideas' — was introduced in the beginning of 2001. 
The first step in our Nordic research project was to conduct interviews with top decision-makers on the making of Nordea. A total of 53 interviews were conducted. All interviews were carried out by a researcher representing the same nationality as the interviewee, using a shared native tongue. The interview material for this specific article consists of interview statements made by some 40 male senior executives representing three different nationalities: Danish, Finnish and Swedish. Interviews with Norwegian respondents are not included here.

Our standard interview guide covered a range of topics. Two questions on gender equality were included: 'Has equality between the sexes emerged as an issue in the negotiations or integration decision-making?' and 'How has the cross-border dimension changed views and policies concerning equality?' These two questions were to be asked towards the end of each interview, together with questions on topics such as knowledge transfer and learning. These topics followed questions about the negotiations and the integration processes vis-à-vis the mergers and acquisitions in the making of Nordea.

Our focus here is on accounts produced in interviews conducted in a specific local, organizational and socio-cultural context. An interview is a socially and liguistically complex situation. Analysing text produced in interviews calls for conscious and consistent efforts to view the subject matter from different angles (Alvesson, 2003). We are aware of the fact that we have taken the initiative in the interviews: we have introduced the gender issue, we have asked certain questions, we have commented on answers and otherwise contributed to the interviewees' accounts, both formally through turn-taking and through a continual negotiating of meanings. As interviewers, we were both the initiators of the social interactions and the managers' audience in a specific, local socio-cultural context.

In spite of the interview guide, initially agreed upon within the team of researchers, the interviews did not all take the same form. The way in which the questions on equality between the sexes were posed in the interview situation varied. For example, one of the female researchers in our project carried out the interviews alone. An experienced senior academic, she reflects: 
I sometimes felt almost embarrassed asking questions on gender in this specific context because it seemed to totally break the flux of storytelling and sensemaking about the merger integration process. I sensed that my interviewees just paid lip-service [on equality] to me as a woman of the same age and in a certain career position.

This is exemplified in the following interview statement:

Danish male senior executive: I would really like to employ some women. And if I have to choose among two equally competent candidates, I am well aware that we must recruit some women, so this is what will be done. And I notice that the women in our group of managers contribute well and add value to debates that the men tend to forget. They have another managerial style, but this is fine, too. We just have never taken any initiative to solve this problem.

It is, of course, debatable whether this is 'lip-service' or whether the statement reflects some form of material reality. Based on her studies in Norway and Sweden, Kvande (1998) notes that men at times construct women as competent, although their attitudes towards gender equality tend to follow discourses of women's deficiency. It is evident in our interview material that a repertoire of discourses is present and that the use of these discourses needs to be interpreted with careful consideration of the context of their production.

The female interviewer interacting with Danish executives decided in many situations to abandon the original questions from the interview guide and to find other ways to inquire about gender (in)equality. On occasions she chose to introduce gender and equality in relation to human resources issues emerging at Nordea. Just as in the quote in the introduction of this article, the exchange of words below shows how nationalities and national identification enter the picture when gender-related issues are discussed in the crossborder context: 
Female interviewer: Does gender play a role in relation to recruitment, maintenance and when you discuss whether some of the employees do not meet your success criteria?

Danish male senior executive: No, I don't think gender is an issue in these specific contexts. We are confronted with the issue, and we try to work consciously with it in relation to career development and executive training. But we have very different structures in the different countries. I think 80 per cent of the employees in Finland are women. In Denmark it is about fifty-fifty. I have never heard anyone talk about gender in relation to recruitment in Denmark. But in Sweden they work actively to make the issue visible; they push and encourage women to accept managerial positions.

It is also notable that questions on gender equality typically did not 'fit in' the interview situation. The interviewers sensed this, as the interviewees were often somewhat surprised by questions on gender. This can be seen in the following:

Male interviewer: . . has the equality question been discussed?

\section{Finnish male senior executive: Equality?}

Male interviewer: I mean between men and women.

Finnish male senior executive: Men and women: well, this equality issue emerges, according to my experience, it has now emerged primarily in relation to shareholders' meetings. Always, because it sort of comes from the outside. We know it's coming. And it is concerned with these questions of line-up [that is, the distribution of sexes in management]. It is a sort of a regular topic and it is discussed a bit and one has really genuinely sought candidates for the board. Butfor the time being it has not succeeded. 
Such experiences in the interviews are, of course, not unique. A number of researchers have pointed out how (talk about) sex or gender — here, 'this equality issue' - is often presented as out of place in organizational life. 'It sort of comes from the outside.' In the Finnish context, Korvajärvi (1998, 2002) has explored ways in which gender is distanced from everyday life by organizational members. Questions of gender equality and inequality can be distanced spatially or temporally. In spatial distancing, the basic message is that in our organization the situation is all right, but there are problems in other organizations. Distancing can also be accomplished temporally, in the vein that things used to be bad here, but now they are all right (Hearn, 1998). With the interview experiences, distancing emerged as a core concept for our analysis of social interactions vis-à-vis the concepts of gender and (in)equality. It provides us with a lens to consider the role that language plays in the construction and reconstruction of domination: in this case, excluding women from top positions (Fairclough, 1997).

We then worked with the interview material in the following way. The questions and responses related to gender - and the discussions that followed in the interviews were extracted from verbatim interview transcripts. These pieces of text were read and reread individually by the authors of this article and subsequently discussed. In the case of the Finnish texts, selected pieces were translated into English and thus made available for non-Finns (the Finns involved in this project are able to read Scandinavian languages).

These readings set out a process through which meanings in the texts were discussed among the research team. The Danish author of this article carried out all interviews with the Danish executives in the first step of the Nordea project. The two Finnish authors of this article each carried out a number of individual interviews with Finnish executives, splitting the fieldwork between them. The Swedish author of this article occupied a different position. She did not carry out any fieldwork; she has only 'met' the senior executives through the text. In this way, she brings an invaluable outsider's perspective to the analysis presented in this article, particularly in considering the interaction between each researcher and interviewee (the researcher who conducted the interviews in Sweden was consulted several times on her experiences as well as our interpretations of the texts). 
The interview extracts were grouped on the basis of the interviewee's nationality. Focusing on the ways in which each executive accounted for the lack of women in top positions at Nordea, similarities and differences within each national group were elucidated and, subsequently, these similarities and differences were compared across the national groups. The discursive means through which the executives used national categorizations for justifying their own viewpoints and practices were then singled out; bearing in mind the interaction between the interviewee and the researcher.

The leading author began to sketch an outline for what seemed to be recurring accounts in the texts for each nationality (this provided the basis for the empirical part of this article). This outline was then reworked in several stages. In presenting our research findings, we first tried out a story or narrative approach (see Tienari et al., 2002b), but soon realized that we had difficulties in applying this approach on the empirical material. We continued with discourse analysis.

The first stages in the analysis brough to the fore particular issues in carrying out cross-cultural research with a cross-cultural team. Initial disagreements on the interpretation of the texts were few, and concerned mainly the question of how illustrative the comments and reflections on gender (and nationality) were for Danes, Finns and Swedes respectively. Three of the authors of this article had similar experiences when they conducted a discourse analysis of national stereotypes of self and others emerging in the same interviews (Vaara et al., 2003b), and this parallel work enhanced the reflections on the interpretations made vis-à-vis gender. Also, our backgrounds in different academic disciplines emerged as something that needed to be discussed during the research process. In spite of a shared stance on the role of language in the construction of social reality, we noticed that our interpretations of statements on the way gender and equality did not fit in the interviews (and we regarded this as a crucial element in the research) was consonant with each researcher's knowledge of feminist organization studies. In the end, we feel that our different national and academic backgrounds helped us form a rich and multifaceted understanding of the phenomena at hand.

However, it is important to note that what we present in the following should not be seen as representing or mirroring the Nordea male senior executives' organizational 
reality as such. Our empirical material is the executives' construction of more or less coherent accounts of themselves and others in their social interaction and negotiation of meaning with us in the interview situation (Alvesson and Deetz, 2000; Gabriel, 2000). Our analysis is informed by our knowledge of the field, the societal context and the theoretical concepts (such as gender and national identity) we have used as our lenses. What follows below is our social construction of the executives' constructions (Linstead and Thomas, 2002; Meriläinen et al., 2004).

\section{(Re)constructing gender and national identity at Nordea}

Senior executives at Nordea represent an interesting cadre of business professionals. They are survivors of a number of mergers and acquisitions, where others have been forced to leave the organization. They operate in an increasingly global market. In this position, the executives are expected to be constantly mobile. In the initial stages of the cross-border mergers, for example, Nordea did not have one distinct headquarters. Executives spent a large amount of time moving around the Nordic capitals: Copenhagen, Helsinki, Oslo and Stockholm. They frequently meet other business professionals in financial centres such as London, Brussels, Luxembourg and New York.

\section{Distancing gender inequality}

Before proceeding to the topical area of the (re)construction of national identities as a means to distance gender (in)equality, we would like to raise three issues. Firstly, it is important to note that, in the Nordic context, male senior executives seem to be well aware of the fact that the lack of women in top management is a potentially sensitive topic. Gender equality in general, and the representation of women in top management in particular, is a topic that is likely to be raised in public by actors such as journalists and individual shareholders. Articulating such pressures that emerge 'from the outside' (as in the quote above) demonstrates how senior executives seek to downplay questions on gender. 'It is not an operating problem', as one of the executives said. In their accounts in the interview situation, executives acknowledge the equality issue, but blur its links with 
the core function of the company, which is to conduct business profitably. Inequality and the correction of gender bias are thus distanced outside the boundaries of the organization.

Secondly, it is evident that accounting for an absence of women in top management can be accomplished through historical reflection, where the past is explicitly drawn upon to make sense of, and justify, the present situation. The absence of women is justified through remarks on how there have not been suitable (sic) female candidates for top positions when decisions had to be made. In this sense, 'there hasn't been a problem', as one of our interviewees put it. The selection of top managers has, in this discourse, been based on competence acquired by experience. In other words, the definition of top management competence is presented by the executives as gender neutral, not as something shaped according to a specific interpretation of maleness or masculinity. Questions of equality and inequality are, again, distanced as something alien to the normal flow of organizational life.

Thirdly, distancing inequality can be accomplished by constructing relatively traditional views on the distinction and separation between public and private spheres of life. This reflects a point of view that it remains the responsibility of women to take care of the home and the family. By articulating motherhood as incompatible with taking top managerial responsibility, we argue, senior executives at Nordea distance inequality to the societal level. As one of the executives said: 'You don't do the job as a mother of a family: that doesn't work, you must give up something, and it is still easier for a man to take that step.'

The crux of this justification seems to be that, due to arrangements on how families (with children) function, women are not able to 'give up' the 'something' that is needed and expected from senior executives in the increasingly competitive world of business (Calás and Smircich, 1993; Höök, 2001). 6 Viewed in the context of the Nordic welfare states, which have in the recent decades allowed women with children to advance in the labour market, the discursively constructed nature of such distinctions between work and family is apparent. This discourse strengthens the (re)construction of managers and management according to the core family and malebreadwinner model. Through such 
discourse, we suggest, decision-makers in multinationals may impact on the erosion of the gender egalitarian aspects of the Nordic model.

\section{Gender and national identities}

Our first examples of how gender and national identity intersect are from interview situations involving a male Danish senior executive and a female Danish researcher. In general, it seems that the prevalent image of the businessman - or business man constructed in the discourse drawn on by Danish executives relates to what Collinson and Hearn (1994) have labeled 'informalism'. We term this image in the present context as a 'relaxed tough guy', which relates to a specific form of aggressiveness and disregard for formal equality procedures. Key attributes of male Danishness vis-à-vis the (in)equality question are flexibility and informality.

The statement, 'We have a different culture in Denmark', quoted in the introduction, explicitly implies that procedures which work in Sweden and Finland do not work in Denmark. To view 'gender' as something significant' is constructed by this executive as something alien to what he considers as Danishness. Other examples of this are remarks such as, 'The weak point of the girls [that is, women in managerial positions] is that they are not able to just sit down and have a beer with their colleagues when there is complete chaos. You observe that the girls simply put too much stress on their employees: they are nearly too ambitious; everything must be no less than perfect.' It is notable that Danish executives often refer to 'girls' ( piger ) in talking about women, even in interview sessions with a senior female academic who constantly uses the word 'women' in her questions and comments.

Danish male senior executive: In Finland there are many more women in the company, also in managerial positions. There is no doubt that Finland is no. 1, Sweden no. 2 and Denmark no. 3.

Female interviewer: Are the managerial positions that women hold in the other Nordic countries defined in another way? Do they [that is, women] have other 
areas of responsibility? Or how would you explain the difference? Have you thought about that?

Danish male senior executive: There are some cultures where women are more easily contained. But in Finland there are simply so many women everywhere. You must ask someone else about these questions. I am not an expert in this area. To put it bluntly, I have never spent a minute considering these issues.

As in the exchange of words above, the equality question can be distanced in the Danish discourse by (re)constructing national differences. At one extreme, as presented below, Danish executives may use Swedish women as supporters of the less formal and apparently more flexible (or practical) Danish way of approaching questions of gender equality. Quotas are taken as a negative example of bureaucratizing and formalizing the issue in Swedish organizations:

Female interviewer: But are there any differences between the Nordic countries?

Danish male senior executive: Yes, there is a difference. In Sweden, there is there is not any legislation - but they are close to quota restrictions according to gender. And that's why there is considerable political pressure in Sweden. But, if you go to Sweden and ask women if they want a quota system based on gender, then the answer is, 'No!' But the legislative initiatives move in that direction. The thing is that we do not place nationality either . . . at the top of the agenda when we are looking for specific competencies. Hence, it is difficult to argue in favour of positive discrimination of a certain gender. But, on the other hand, I personally think it would be an advantage for us if we had more women [in managerial positions]. 
And in a similar vein:

Danish male senior executive: We ask, 'Who do we trust?' Then we talk with them about it and say, 'We trust you!' Then we create a network around them and get them in equal positions. We talk about it when we appoint new managers. . . In the name of equality, we also do that for the men, also arrange mentoring for them. This is the direction in which we want to go. The Swedes run courses where the potential female managers are driven through a kind of management education system. . . Gender is a markedly stronger issue in Sweden than in any other Nordic country. It is nearly a kind of mantra.

It is evident that Danish senior executives present Swedish formality - for example, in terms of rigid labour legislation — as a potential obstacle to the flexible management needed in turbulent times in the world of multinational business. As the above extract shows, a more informal procedure encouraging women who are to be 'trusted' is preferred by Danes (or Danish men).

In interview situations involving a male Finnish senior executive and a male Finnish researcher, a different prevalent image of the business man is constructed. This image relates to aspects of paternalism, but also to entrepreneurialism promoting efficiency and control (Collinson and Hearn, 1994). We call this image a "pragmatic man of action'.7 The key message of male Finnishness in the business world is that action speaks louder than words:

Finnish male senior executive: This equality question. . . In Sweden this thing probably gets the most attention, and in Finland it is [present] in a restrained and controlled way. We have an equality plan, we have an equality committee . . and we always talk about it and take steps to realize it. [. . .] I think this discussion is carried out in a restrained way in Finland. In Sweden, these symbols . . that you must do something in a strong way . . are more pronounced. 
Finnishness attains specific meanings in this account. 'Restrained' and 'controlled' action in 'steps' seems to be the core of the male Finnish discourse on gender equality in organizations. Again, national differences ('in Sweden, these symbols') are used to make sense of the present situation at Nordea:

Regarding equality as such, the discussion on the involvement of women has become more active with the Swedes. For them, it is a part of, well, even of style, in the sense that it must be up for discussion. On the Finnish side, we don't so much talk for the sake of talk. Instead, we do something [about it].

Sweden is, again, the reference point here. A typically Swedish feature is contrasted with Finnishness. Swedes talk, and they look for 'symbols'. In the Finnish accounts (as in the Danish ones), Swedes are portrayed as prone to bureaucratize the equality issue, while Finns rely on a more emergent or 'natural' stance:

Finnish male senior executive: We have perhaps promoted more qualified women than elsewhere [in the four Nordic countries]. It really seems that in Sweden you must look closely to find a woman in management.

\section{Male interviewer: How come?}

Finnish male senior executive: Perhaps it is, after all, a more patriarchal society than Finland. Perhaps Finnish women are stronger than the Swedish. They are more enduring.

In the account above, not only Finnish men of action are portrayed as strong. Finnish women, too, are assigned a specific identity: they are 'enduring' individuals and perhaps are 'stronger than the Swedish'. Further, a Swedish system apparently promoting 'quota women' is contrasted with the less rigorous and more pragmatic way of dealing with the equality issue in Finland: 
Finnish male senior executive: It is more pronounced in Sweden. And this comes to the fore as, for example, we have this top management training programme where the way the future potential is taken care of - is sketched. Well, say that in principle you have to have three applicants for a top position, three potential applicants, of which one must be female. That's the Swedish way of expressing this striving for equality. In Finland . . . if I go asking, 'Would you like a quota... in which we have a number of people, of whom two have to be women?' Well, they'd say that we don't want to be quota women. That is a term that has been used. So that's the difference. In Sweden it is talked through, whereas in Finland one does something about it. But principles on quotas are not appreciated. That's where the difference is.

Such Finnish accounts on gender equality call for a short note. Finnish companies with more than 30 employees are required by law to come up with an annual plan for equality and equal opportunity measures. Apart from this, a concrete effort has been made for a number of years in the Finnish part of Nordea to promote equality between the sexes; for example, by correcting pay differentials and ensuring a balanced intake in managerial training programmes. Few male senior executives seem to be aware of these efforts. Projecting 'bureaucratic measures' as typically 'Swedish' is thus a truly discursive accomplishment.

Finally, in interview situations involving a male Swedish senior executive and a female Swedish researcher, a particular form of masculinity prevails. This relates to Collinson and Hearn's (1994) ideas about paternalism. A prevalent image of what we term a 'responsible man', conscious of the need for equality between the sexes in the organization, is constructed. Male Swedishness is characterized here by a structured and well-planned approach:

Swedish male senior executive: In Sweden, we have rather advanced labour legislation with specific procedures for how appointments and dismissals should be undertaken. You have negotiations with the trade union and so on. In our company plan we have an account of how equality and environmental issues have 
to be carried out. This was something totally new to our Finnish colleagues . . . they had never seen anything like it . . . and they also thought that the procedures to be undertaken were rather elaborate.

In this discourse, formal structures in Swedish legislation are referred to with certain pride. These 'advanced' structures have supported equality and equal opportunity initiatives in Swedish workplaces; this being 'something totally new to our Finnish colleagues' (although, as mentioned above, the legislation is in place in Finland, too). 'I think that we in Sweden have reason to be proud, because these issues have been placed on the top of the agenda', as a Swedish executive put it. Finnish executives, novices in formal equality procedures, are constructed as men of action in the Swedish accounts, too:

Swedish male senior executive: But I have a feeling that in practice equality has a much higher priority in Finland, although it has not been debated so much. In Finland, you don't talk so much, you simply make it work. . . I worked in Finland in the 80s. At that time, the society was gendered, but in the 90s I haven't experienced such differences. On the contrary, qualified girls get the jobs, but they get them simply because they have the [required] competencies. They [that is, the Finns] don't talk so much about it, but they put it into effect.

A note must be added here on 'girl' in the Swedish discourse. The original Swedish word used above is 'tjej', which is relatively neutral and does not convey the same belittlement as 'flicka' (or the Danish 'pige'), which can be considered derogatory when used to denote a woman. The politically incorrect word, 'flicka', was not used once by Swedish senior executives in our interviews.

Swedish male senior executive: I have tried to put it [that is, gender equality] forward, because it is a big issue in Sweden. [. . .] It is an important image issue. But, most importantly, it is a matter of competence development, and it has a bearing on our [future] capacity. We compete to attract a qualified workforce and 
we cannot afford to give up recruiting half of the population. They are part of our potential career force.

In all, Swedish executives construct themselves as being aware of the importance of gender equality issues in the larger societal context both in Sweden and the Nordic countries in general. This links with the importance of sound human resources management for both sexes in the organization. Judging from the Swedish accounts, this is not always supported by 'Danes' (Danish men) who 'sometimes go for the positions in the company in a much too aggressive way', as one of the Swedish executives interviewed put it.

\section{Conclusion}

In this article, we have presented a study of gender (in)equality and national identities in a Nordic cross-border merger context. We have focused on the ways in which male senior executives in a complex multinational setting justify the persistent absence of women in top management. We have analysed how a gendered order - or the marginalization and exclusion of women - is produced and reproduced by male executives when interviewed by researchers. Our analysis is based on the conception that gender exists in and through language, albeit with practical consequences in so far as it produces and reproduces specific practices and positions.

By analysing discursive constructions in interaction between male senior executives and researchers, we have identified recurring discourses that enable executives to distance inequality between the sexes. Distancing inequality can be accomplished in relation to space and time (Hearn, 1998; Korvajärvi, 1998). Discourse articulating pressures from the 'outside', for example, by the media and individual shareholders, enables male executives to distance inequality outside the boundaries of the organization. Discourse on historical continuity, where equality procedures are distanced as alien to the 'normal' flow of organizational life, and discourse on motherhood and responsibilities at home, where inequality is distanced to the societal level, enable executives to justify the lack of women in top management. Fatherhood is notably absent from such discourse: it 
is thus rendered unproblematic. All these ways of organizing (in)equality and of maintaining patterns of domination are well documented in feminist literature. Both the literature and our analysis shows that, while public discourse in Nordic societies still nurtures gender equality and equal opportunities, managers and management is constructed according to the core family and male-breadwinner model (Holgersson, 2001; Tienari et al., 2003; Wahl, 1995).

We argue that the multinational organization intensifies such discursive constructions. The multinational is a significant contemporary arena for (re)producing particular relations of domination. It is an arena where gender inequality is constructed and reconstructed. In the discursive constructions of the senior executives interviewed, a specific type of man prevails; business-oriented and competitive, mobile and fully committed to work (see also Acker, 1990, 1998; Collinson and Hearn, 1994; Kerfoot and Knights, 1993). Issues such as profit and efficiency are emphasized and are sharply distiguished from issues such as equality between the sexes. Consequently, it can be argued that the discursive possibilities seem rather limited for the Nordic male senior executives in the increasingly global, toughening, business landscape (Meriläinen, 2000). Judging from the senior executives' talk, it is evident that dominant corporate management discourse works to override Nordic societal discourse. It may even be that, for its part, such management discourse contributes to the eroding of the Nordic model of a welfare society.

We do, however, also claim that society and nations continue to matter. In the cross-border merger setting, for example, national identification plays a key role when the people involved make sense of their new situation, their role and their own identity and that of others, of the organizational changes they experience and of their joint future. The interesting thing about these identifications is not whether they represent 'facts' or refer to any particular kind of organizational 'reality', but that they — at a certain time and in a specific context - represent shared meanings.

Consequently, it is evident that there are varieties in the discursive constructions of the competitive man of global business. Perceptions of national differences persist. The main contribution of this article lies in identifying and analysing discourses that (re)construct national identities, where gender inequality is distanced to other national 
collectives within the multinational. It is evident that a complex cross-national merger setting presents key organizational actors with particular opportunities to distance inequality through constructing images of 'us' and 'them' as national collectives. The basic point is that in all national identity constructions, the ways of 'us' are rendered normal and the ways of 'them' strange (Billig, 1995; de Cillia et al., 1999; Wodak et al., 1999).

In all, our study shows that male senior executives constitute national differences when they justify gender inequality in the multinational organization. These accounts are accomplished through notions of distinct nationalities; here, Danish, Finnish and Swedish. Our research also offers new insights to some of the methodological and analytical challenges involved in studying gender in multinationals with a cross-cultural team of researchers.

We suggest that a relevant avenue for developing the present research is to focus more closely on the idea of co-authorship in interviews between researchers and corporate executives. Bringing up gender equality concerns may cause discomfort in interview situations where questions on gender do not seem to 'fit in' (as discussed in the section on conducting and reading interviews above). Bringing in discourse on national differences may then turn a setting where the interviewee and interviewer initially find

themselves on opposite sides (that is, questioning and answering about gender) into a situation with a common ground (that is, framing a shared national identity) where apparent problems related to gender equality and inequality can be objectified. In all, we suggest that more research is needed on the 'local' and 'national' in relation to the global in doing gender in the contemporary world of business.

\section{Notes}

1. We understand gender as socially and culturally constructed, maintained and changed through discourse. Gender exists in and through language, but it has practical consequences in so far as it produces and reproduces specific practices as well as positions - either oppressive or empowering - for individuals in organizations. We study gender in (and through) discourse, which can, in our work, be defined as language 
that reflects and constructs social reality. 'Discourse is the principal means by which organization members create a coherent social reality that frames their sense of who they are' (Mumby and Clair, 1997, p. 181). Discourse analysis, as we see it, is a methodology that examines the role that language plays, in different ways, in the construction of power relationships and the reproduction of domination (Fairclough, 1997). In this way, we treat masculinities and femininities, for example, as discursive phenomena and thus as constantly changing, even though the senior executives may tend to reduce men and women to fixed and unitary categories in social interactions such as interviews (Cockburn, 1991). Similarly, the concepts of nation and nationalities are treated as discursive constructs (Anderson, 1983; Billig, 1995; Wodak et al., 1999). Overall, our analysis is based on a careful contextualization of the interview texts.

2. Generally speaking, other sources of individual and collective identity may be in play in interview situations: age or generation, occupation, race, religion, sexual orientation and so on. Due to the theoretical focus here, these are not discussed further in this article.

3. The burgeoning literature on postcolonialism and neocolonialism may provide another source of inspiration for studying gender vis-à-vis nationalism and national identity. The potential unity between postcolonialism and feminism, however, remains contested (Gandhi, 1998).

4. For us, the concept 'transnational' refers first and foremost to operations across more than one nation and across national borders, but also to the division of ownership and management between two or more nations. We use it interchangeably with the term 'multinational' (for a discussion, see Hearn and Kovalainen, 2000). The formation of multinationals is one aspect of globalization, which we realize is a contested term, covering a multiplicity of (gendered) processes and practices (Acker, 1998).

5. The researchers involved in the project are (in alphabetical order): Ingmar Björkman (Swedish School of Economics, Helsinki), Karl-Olof Hammarkvist (Stockholm School of Economics), Charlotte Holgersson (Stockholm School of Economics), Tore Hundsnes (the Norwegian School of Economics and Business Administration), Christine B. Meyer (the Norwegian School of Economics and Business Administration), Annette Risberg (Copenhagen Business School), Anne- Marie 
Søderberg (Copenhagen Business School), Janne Tienari (Lappeenranta University of Technology) and Eero Vaara (Swedish School of Economics, Helsinki and Ecole de Management de Lyon).

6. According to Höök's (2001) study in Sweden, constructions of fatherhood and management are mutually reinforcing, while the constructions of motherhood and management undermine each other (see also Hearn and Parkin, 1987). This is an all too familiar story. Kanter (1977) argues that a (male) manager requires the emotional and practical contributions of a wife or partner. For women attempting to pursue a career, family and motherhood continue to be a drawback. Conceptions of motherhood are embedded in the 'cultures' of companies (Andersson, 1997; Asplund, 1988; Eriksson, 2000).

7. We borrow this term from Berglund and Werr (2000), who use it in a slightly different contextual meaning.

\section{References}

Aaltio-Marjosola, I. (2001) Naiset, miehet ja johtajuus. (Women, men and leadership.) Helsinki: WSOY.

Abrahamson, L. (2000) Attåterställa ordningen. Könsmönster och förändring $i$ arbetsorganisationer. (To restore order - gender patterns and change in work organizations.) Umeå, Sweden: Boréa.

Acker, J. (1990) Hierarchies, jobs, bodies: a theory of gendered organizations. Gender and Society, 4,2, 139-58.

Acker, J. (1994) The gender regime of Swedish banks. Scandinavian Journal of Management, 10,2, 117-30.

Acker, J. (1998) The future of 'gender and organizations': connections and boundaries. Gender, Work \& Organization, 5,4, 195-206. 
Adib, A. and Guerrier, Y. (2003) The interlocking of gender with nationality, race, ethnicity and class: the narratives of women in hotel work. Gender, Work \& Organization, 10,5, 413-32.

Alvesson, M. (2003) Beyond neopositivists, romantics, and localists: a reflexive approach to interviews in organizational research. Academy of Management Review, 28,1, 13-33.

Alvesson, M. and Deetz, S. (2000) Doing Critical Management Research. London: Sage. Anderson, B. (1983) Imagined Communities: Reflections on the Origin and Spread of Nationalism. London: Verso and NLB.

Andersson, G. (1997) Karriär, kön och familj. (Career, gender and family.) In Nyberg, A. and Sundin, E. (eds) Ledare,makt och kön, SOU 1997:135, Stockholm: Fritzes.

Anttonen, A. (1997) Feminismi ja sosiaalipolitiikka — miten sukupuolesta tehtiin yhteiskuntateoreettinen ja sosiaalipoliittinen avainkäsite. (Feminism and social policy how gender was made into a core concept in social sciences theory and social policy.) Tampere: University of Tampere Press.

Asplund, G. (1988) Women Managers. Changing Organizational Cultures Chichester: Wiley.

Åström, G. (1995) Society in a gender perspective. In Wahl, A. (ed.) Men's Perceptions of Women and Management, pp. 9-13. Sweden: Ministry of Social Affairs.

Benschop, Y. and Doorewaard, H. (1998) Covered by equality: the gender subtext of organizations. Organization Studies, 19,5, 787-805. 
Benschop, Y., Halsema, L. and Schreurs, P. (2001) The division of labour and inequalities between sexes: an ideological dilemma. Gender, Work \& Organization, 8,1, $1-18$.

Berglund, J. and Werr, A. (2000) The invincible character of management consulting rhetoric: how one blends incommensurates while keeping them apart. Organization, 7,4, 633-55.

Bergqvist, C. (ed.) (1999) Likestilte demokratier? Kjønn og politikk i Norden. (Equal democracies? Gender and politics in the Nordic region.) Oslo: Universitetsforlaget. Billig, M. (1995) Banal Nationalism. London: Sage.

Borchorst, A., Christensen, A-D. and Siim, B. (2002) Diskurser om køn, magt og politik i Skandinavien. (Discourses on gender power and politics in Scandinavia) In Borchorst, A. (ed.) Konsmagt under forandring, pp. 246-66. Copenhagen: Hans Reitzel.

Buono, A.F., Bowditch, J.L. and Lewis, J.W. III (1985) When cultures collide: the anatomy of a merger. Human Relations, 38,5, 477-500.

Calás, M.B. and Smircich, L. (1992) Using the F-word: feminist theories and the social consequences of organizational research. In Albert Mills, A. and Tancred, P. (eds) Gendering Organizational Analysis, pp. 222-34. Newbury Park, CA: Sage Publications.

Calás, M.B. and Smircich, L. (1993) Dangerous liaisons: the 'feminine in management' meets 'globalization'. Business Horizons, 36,2, 73-83.

Calás, M.B. and Smircich, L. (1999) Past postmodernism? reflections and tentative directions. Academy of Management Review, 24,4, 649-71.

Calori, R., Lubatkin, M. and Very, P. (1994) Control mechanisms in cross-border acquisitions: an international comparison. Organization Studies, 15,3, 361-79. 
Cockburn, C. (1991) In the Way of Women. London: Macmillan.

Collins, P.H. (1990) Black Feminist Thought: Knowledge, Consciousness, and the Politics of Empowerment. New York: Routledge.

Collinson, D. and Hearn, J. (1994) Naming men as men: implications for work, organization and management. Gender, Work \& Organization, 1,1, 2-22.

Connell, R.W. (1995) Masculinities. Cambridge: Polity Press.

Connell, R.W. (2000) The Men and the Boys. Cambridge: Polity Press.

Connell, R.W. (2001) Masculinity Politics on a World Scale. In Whitehead, S.M. and Barrett, F.J. (eds) The Masculinities Reader, pp. 367-74. Cambridge: Polity Press.

Czarniawska-Joerges, B. (1994) Editorial: modern organizations and Pandora's box. Scandinavian Journal of Management, 10,2, 95-98.

De Cillia, R., Reisigl, M. and Wodak, R. (1999) The discursive construction of national identities. Discourse and Society, 10,2, 149-73.

Donaldson, M. (1993) What is hegemonic masculinity? Theory and Society, 22,5, 64357.

Duncan, S. (1998) Theorising gender systems in Europe. In Geisler, B., Maier F. and Pfau-Effinger, B. (eds) FrauenArbeitsMarkt, pp. 195-227. Berlin, Edition Sigma.

Eriksson, U. (2000) Det mangranna sällskapet. Om konstruktion av kön i företag. (Companions to men: constructing gender in business.) Gothenburg: BAS Förlag. 
Esping-Andersen, G. (1990) The Three Worlds of Welfare Capitalism. London: Polity Press.

Fairclough, N. (1997) Critical Discourse Analysis: The Critical Study of Language. London: Longman.

Gabriel, Y. (2000) Storytelling in Organizations: Facts, Fictions and Fantasies. Oxford: Oxford University Press.

Gandhi, L. (1998) Postcolonial Theory: A Critical Introduction. Edinburgh: Edinburgh University Press.

Gertsen, M., Søderberg, A-M. and Torp, J.E. (1998) Different approaches to the understanding of culture in mergers and acquisitions. In Gertsen, M.C., Söderberg, A-M. and Torp, J.E. (eds) Cultural Dimensions of International Mergers and Acquisitions, Berlin and New York: de Gruyter.

Gherardi, S. (1994) The gender we think, the gender we do in our everyday organizational lives. Human Relations, 47,6, 591-610.

Gioia, D. and Chittipeddi, K. (1991) Sensemaking and sensegiving in a strategic initiation. Strategic Management Journal, 12,6, 433-48.

Gundelach, P. (2000) Joking relationships and national identity in Scandinavia. Acta Sociologica, 43,2, 113-22.

Hearn, J. (1996) Deconstructing the dominant: making the one(s) the other(s). Organization, 3,4, 611-26. 
Hearn, J. (1997) The implications of critical studies on men. NORA, 3,1, 48-60. Hearn, J. (1998) The Violences of Men: How Men Talk about and How Agencies Respond to Men's Violence to Women. London: Sage Publications.

Hearn, J. and Kovalainen, A. (2000) Gender Relations in Transnational Organisations: A Theoretical, Conceptual and Methodological Overview. Swedish School of Economics and Business Administration, Finland, Working Paper 450.

Hearn, J. and Parkin, W. (1983) Gender and organisation: a review and a critique of a neglected area. Organization Studies, 4,3 219-53.

Hearn, J. and Parkin, W. (1987) 'Sex' at 'Work'. London: Wheatsheaf Books. Hogan, J. (1999) The construction of gendered national identities in the television advertisements of Japan and Australia. Media, Culture \& Society, 21,6, 743-58.

Højgaard, L. (2002) Tracing differentiation in gendered leadership: an analysis of differences in gender composition in top management in business, politics and the civil service. Gender, Work \& Organization, 9,1, 15-38.

Holgersson, C. (2001) The social construction of top executives. In Sjöstrand, S-E., Sandberg, J. and Tystrup, M. (eds) Invisible Management: The Social Construction of Leadership, pp 105-25. UK: Thomson Learning.

Höök, P. (2001) Management as uncontrollable sexuality. In Sjöstrand, S-E., Sandberg, J. and Tystrup, M. (eds) Invisible Management: The Social Construction of Leadership, pp. 149-66. UK: Thomson Learning.

hooks, b. (1984) Feminist Theory: From Margin to Center. London: Pluto Press. 
Jacobson, S.W. and Aaltio-Marjosola, I. (2001) 'Strong' objectivity and the use of QMethodology in cross-cultural research: contextualizing the experience of women managers and their scripts of career. Journal of Management Inquiry, 10,3, 228-48.

Kanter, R.M. (1977) Men and Women of the Corporation. New York: Basic Books. Kerfoot, D. and Knights, D. (1993) Management, manipulation and masculinity: from paternalism to corporate strategy in financial services. Journal of Management Studies, 30,4, 659-77.

Korvajärvi, P. (1998) Gendering dynamics in white-collar organizations. Ph.D. dissertation, University of Tampere. Acta Universitatis Tamperensis 600.

Korvajärvi, P. (2002) Gender-neutral gender and denial of difference. In Czarniawska, B. and Höpfl, H. (eds) Casting the Other. The Production and Maintenance of Inequalities in Work Organizations. London: Routledge.

Kvande, E. (1998) Paradoxes of Gender and Organizations: Gender, Organizations and Change. Trondheim, Norway: NTNU.

Laine-Sveiby, K. (1987) Svenshet som strategi. (Swedishness as strategy.) Stockholm: Timbro.

Laine-Sveiby, K. (1991) Suomalaisuus strategiana. (Finnishness as strategy.) Porvoo: WSOY.

Linstead, A. and Thomas, R. (2002) 'What do you want from me?': a poststructuralist feminist reading of middle managers' identities. Culture and Organization, 8,1, 1-21.

Lubatkin, M., Calori, R., Very, P. and Veiga, J. (1998) Managing mergers across borders: a two nation test of nationally bound administrative heritage. Organization Science, 9,6, 670-84. 
Melkas, H. and Anker, R. (1998) Gender Equality and Occupational Segregation in Nordic Labour Markets. Geneva: International Labour Office.

Meriläinen, S. (2000) Discourses of equality and difference in bank managers' talk. LTA / The Finnish Journal of Business Economics, 3/2000, 416-32.

Meriläinen, S., Tienari, J., Thomas, R. and Davies, A. (2004) Management consultant talk: a cross-cultural comparison of normalising discourse and resistance. Organization $11,4,539-64$.

Mumby, D.K. and Clair, R.P. (1997) Organizational discourse. In Teun, A. van Dijk (ed.), Discourse as Social Interaction, pp. 181-205. London: Sage Publications.

Nahavandi, A. and Malekzadeh, A.R. (1988) Acculturation in mergers and acquisitions. Academy of Management Review, 13,1, 79-90.

Nkomo, S. (1992) The emperor has no clothes: rewriting 'race in organizations'. Academy of Management Review, 17,3, 487-513.

Olie, R. (1994) Shades of culture and institutions in international mergers. Organization Studies, 15,3, 381-405.

Risberg, A., Tienari, J. and Vaara, E. (2003) Making sense of a transnational merger: media texts and the (re)construction of power relations. Culture and Organization, 9,2, 121-37.

Smith, D. (1988) The Everyday World as Problematic. Boston: Northeastern University Press. 
Søderberg, A-M. (2003) Sensegiving and sensemaking in an integration process: a narrative approach to the study of an international acquisition. In Czarniawska, B. and Gagliardi, P. (eds.) Narratives We Organize By. Narrative Approaches in Organization Studies, pp. 3-35. Amsterdam/Philadelphia: John Benjamins.

Søderberg, A-M. and Vaara, E. (eds) (2003) Merging Across Borders: People, Cultures and Politics. Copenhagen: Copenhagen Business School Press.

SOU (2003) Mansdominans i förändring: om ledningsgrupper och styrelser. (Shifting male dominance: on management groups and boards of directors.) Stockholm: Fritzes.

Statistics Sweden (2002) Women and Men in Sweden: Facts and Figures. Örebro: SCB. Sundin, E. (2000) Women and men as managers in a female dominated sector and company. LTA/The Finnish Journal of Business Economics, 3, 394-415.

Theobald, H. (1999) Geschlecht, qualifikation und wohlfahrtsstaat. Deutschland und Schweden im vergleich. (Gender, qualifications and the welfare state: Germany and Sweden compared.) Berlin: Edition Sigma.

Tienari, J. (2000) Gender segregation in the making of a merger. Scandinavian Journal of Management, 16,2, 111-44.

Tienari, J., Holgersson, C., Meriläinen, S., Søderberg, A-M. and Vaara, E. (2003) 'We need more women in managerial jobs' - gender equality and management in the Nordic context: deconstruction and critical perspectives. Comportamento Organizacional $e$ Gestao, 9,2, 147-61.

Tienari, J., Quack, S. and Theobald, H. (2002a) Organizational reforms, 'ideal workers' and gender orders: a cross-societal comparison. Organization Studies, 23,2, 249-79. 
Tienari, J., Søderberg, A-M., Holgersson, C. and Vaara, E. (2002b) Narrating gender in a cross-border merger context: nordic executives excusing for inequality. Paper presented at the 18th European Group for Organization Studies Colloquium, Barcelona, Spain, July $4-6$.

Vaara, E., Risberg, A., Søderberg, A-M. and Tienari, J. (2003b) Nation talk: reconstructing national stereotypes in a merging multinational. In Søderberg, A-M. and VAARA, E. (eds) Merging across Borders: People, Cultures and Politics, pp. 61-86.

Copenhagen: Copenhagen Business School Press.

Vaara, E., Tienari, J. and Säntti, R. (2003a) The international match: metaphors as vehicles of social identity-building in cross-border mergers. Human Relations, 56,4, 41951.

Vanhala, S. (1999) Yksityisen sektorin johtajamarkkinat lamasta nousuun. (Private sector management in the recovering managerial labour market.) In Veikkola, E-S. (ed.) Onko huipulla tyyntynyt. Helsinki: Tilastokeskus/Työmarkkinat 1999: 12. 